\title{
A Paradigm Development of Community Learning Management in the Small Sized School in Buri Ram Province Thailand
}

\author{
Kovit Kiyasit, Phatchanee Kultanan, Kovit Vajarintarangoon, \\ Benchaporn Wannupatam, Chaloemchai Sosutha*, Suwimon Chusuwan \\ Faculty of Education, Buriram Rajabhat University, Thailand
}

\section{Article History: \\ Received: September $18^{\text {th }}, 2018$ \\ Revised: November $17^{\text {th }}, 2018$ \\ Accepted: December $19^{\text {th }}, 2018$ \\ Published: December 30 3018}

$\overline{\text { Keywords: }}$

Community-based learning,

Creative thinking,

Small sized schools.

*Correspondence Address:

chalumchai.ss@bru.ac.th

\begin{abstract}
The objectives from this research were to 1) develop and find out the efficiency of a community-based learning paradigm to promote creative thinking for teachers in the small-sized school, 2) study the effectiveness of a community based learning paradigm management to promote creative thinking for teachers in the smallsized school, and 3) study the satisfaction of developing a community-based learning paradigm as a creative thinking paradigm for teachers in the small-sized school. This research was Research and Development (R\&D) combined with the design of a single sample system. The research instrument used in the research was a learning management paradigm community based learning with three learning units and creative thinking evaluation form. The data was analyzed by average, standard deviation, and t-test dependent. The findings of this research are: 1) The efficiency of a community-based learning paradigm to promote creative thinking for teachers in the small-sized school in Buri Ram Province was 81.20/82.50, 2) The effectiveness of a community-based learning paradigm to promote creative thinking for teachers in the small-sized school in Buri Ram Province was that post-training session based on the paradigm of community-based learning management was higher than pre-training session significantly at 0.05 , and 3 ) satisfaction in developing a community-based learning paradigm to promote creative thinking for teachers in the small-sized school in Buri Ram Province was very high. This study implies that the learning paradigm of the community needs to be applied so that creative thinking skills could be improved.
\end{abstract}

\section{INTRODUCTION}

The society of the $21^{\text {st }}$ century world is a knowledge society and a lifelong learning community (Chantarasomabat, Udombunyanuparb, \& Kenchaiwong, 2017; Gardner, 2010). Recently, educational management aims to educate people in the country to be good, clever, and happy (Chang, Chang, \& Yang, 2009). Objectives of educational programs require students to learn to know, learn to be, and learn to do (Marzano, 2003). The education system aims people to have desirable characteristics as a citizen of the nation and learn to live together. For creating desirable characteristics as a world population in the $21^{\text {st }}$ century, the way of education has been changed by focusing on higher-order learning skills, especially evaluation skills that are replaced by the ability to use new knowledge creatively (Burke, Sears, Kraus, \& Cady, 2014; Good, 1973; Nesterova, 2017). School does not focus on grades, as the results, it focuses on the ways to train students to 
prepare for future life in the real world (Shernoff, Sinha, Bressler, \& Ginsburg, 2017). Moreover, it aims to prepare learners for lifelong learning by being flexible in the ways to teach. Classroom activities need to encourage and motivate students to have the skills to think and strive for knowledge when they graduate (Fernández, 2018; Mutakinati, Anwari, \& Yoshisuke, 2018).

Education for new century focuses on the development of children's minds (Yildırım \& Akamca, 2017). The requirement for new generations expects that Thai people have skills and the process of thinking, analyzing, problems solving, and being curious (Wallach \& Nathan, 1965). These can be applied with the knowledge properly to develop themselves continuously to fulfill their potential. One of them is by establishing a community to improve knowledge.

Community is a learning place for people to develop a learning process that is consistent with local needs (Siri \& Chantraprayoon, 2017). Knowledge of the community is learning about problem management and community adaptation as known as local wisdom. The wisdom that comes from real experiences is integrated in terms of physical, mental, social, and environmental knowledge based on culture (Murphy \& Timmins, 2009; Siri \& Chantraprayoon, 2017). There is a deep link to the abstract which emphasizes the importance of ethics rather than materialism (Yin, 2003). Community learning is highly dynamic lifelong learning and problem solving. It is a process of learning that collaborates and reduces conflicts (Francis, M, L, \& Colbry, 2016). It is a powerful tool for raising people and community development. This leads to thinking and solving problem.

Small schools have many urgent problems; 1) The budget is not enough for a high quality education. The school budget is based on the number of students. When the number of students is decreased, the budget will be reduced. The shortage of equipment and necessary teaching aids, especially the lack of textbooks and exercise book leads to lacking effectiveness in learning and teaching (Biggs, 1999). 2) The rate of teachers and learning areas does not complete with the subjects in the curriculum (Borg, Kallenbach, Morris, \& Friebel, 1969). At present, the whole system of primary school teachers is in short supply. 3) Teachers and learners lack the opportunity to use modern technology in learning and teaching (Haruthaithanasan, 2018). 4) Parents ignore their children education. In particular, some children were left with their grandparents because their parents need to work in the city. These children lack the close supervision of both family and teachers. One way for children to remain under the supervision of adults, though not families, is to hand over children to training institutions.

The training package is the management of training tools in accordance with the objectives and the learning environment (Divan \& Mason, 2015; Sheydaei, Adibsereshki, \& Movallali, 2015). Each case is appropriate for the students' needs. The training package is divided into three types, training equipment, training sets, and training modules. Training for personal development is very important for the organization because the success of the organization depends on the people who push the whole plan into reality. If an organization has an appropriate person who is well-equipped with the knowledge, skills, and capabilities for the operations, the operations will be relatively smooth.

On the other hand, the implementation of the organization will suffer from various obstacles if those staffs are in short supply. Especially, in the development of creative thinking which is the ability to think in a variety of ways. It can be applied to the theory or the principle which is carefully and 
accurately coined. It leads to the invention and creation of novel or new ideas. In addition to the creative nature, there can be many creative ideas. This may be viewed as a process of thinking rather than thinking. They can use creative thinking in wider dimensions namely, being creative at work, study, or creative activities (Torrance \& Myers, 1962). These dimensions can be from scientific experiments or sports that need to create a creative way. It can be said that it is the characteristic of academic creativity (Selvi, 2006). However, creative thinking is based on creativity. The person can be linked to daily life well (Yoon, Woo, Treagust, \& Chandrasegaran, 2014). Creativity could be formed through academic education.

From this information, the development of students' creative thinking is a continuing issue of Thai education for a long time. The researchers as the instructors, the faculty of education, and the educator have achieved the objectives of the core curriculum in basic education BE 2551. The development of creative thinking in the measurement and evaluation of the National Testing Institute in the field of creative thinking. Teachers lack knowledge in paradigm of learning management for creative thinking. The researchers found that a study in a community-based learning management paradigm to enhance creative thinking for teachers in the smallsized school in Buri Ram Province.

\section{METHOD}

This research was a paradigm development of community learning management for enhancing creative thinking for teachers in the small-sized school in Buri Ram Province. The objectives were to; 1) develop and find out the efficiency of a community-based learning paradigm to promote creative thinking for teachers in the small-sized school in Buri Ram Province, 2) study the effectiveness of a community based learning management learning paradigm to promote creative thinking for teachers in the small-sized school in Buri Ram Province, and 3) study the satisfaction of developing a community - based learning paradigm as a creative thinking paradigm for teachers in the small-sized school in Buri Ram Province (E, 2000). The research methodology was research and development $(\mathrm{R} \& \mathrm{D})$ combined with the design of a single sample system, The One Group Pre-test Post-test Design. Researchers conducted the research and developed the processes in four phrases.

Table 1. Four Phrases in Research and Development

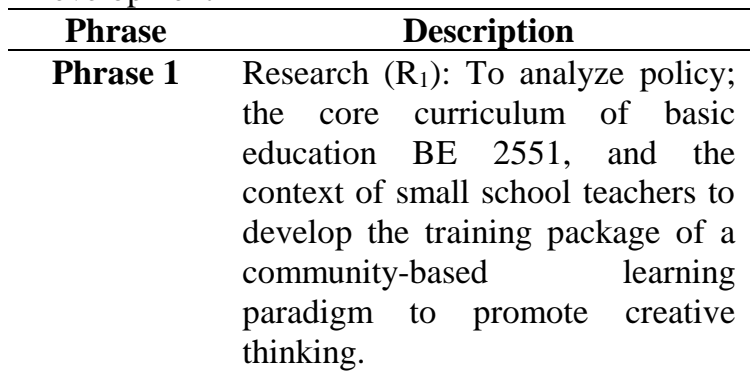

Phrase 2 Development $\left(\mathrm{D}_{1}\right)$ : To design and develop; development and finding out the efficiency of the training package of a community-based learning paradigm to promote creative thinking.

Phrase 3 Research $\left(\mathrm{R}_{2}\right)$ : To implement; trying out the training package of a community-based learning paradigm to promote creative thinking.

Phrase 4 Development $\left(\mathrm{D}_{2}\right)$ : To Evaluate; Development and improvement of the training package of a community-based learning paradigm to promote creative thinking.

The research methodology was research and development (R\&D) (Borg $\&$ Gall, 2003). The sample in this study was 30. To understand and interpret the result of data analysis, the researchers formulated symbols for data analysis as followings. 


$$
\begin{aligned}
\frac{\mathrm{n}}{\bar{X}} & =\text { Number of Samples } \\
\text { S.D. } & =\text { Average Score } \\
\mathrm{t} & =\mathrm{t}-\text { dependent on training package }
\end{aligned}
$$

The flow of research to develop the community-based learning paradigm is as Figure 1.

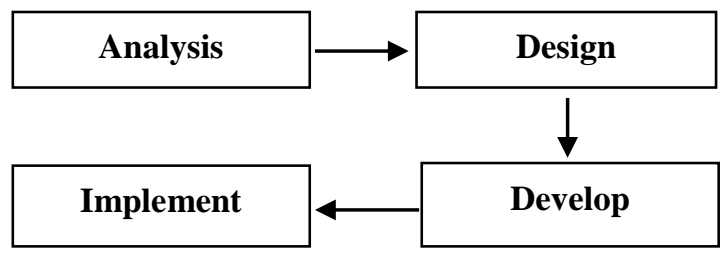

Figure 1. The Flowchart of Research and Development

\section{RESULT AND DISCUSSION Data Analysis}

This research was a paradigm development of community learning management for enhancing creative thinking for teachers in the small-sized school in Buri Ram Province. To analyze the results of training package development for a paradigm development of community learning management for enhancing creative thinking for teachers in the small-sized school in Buri Ram Province by focusing group discussion. Using a technique of focusing group discussion by inviting six experts, three experts of the training package design and three experts of community in the fields, the experts were required to check the tool for a paradigm development of community learning management for enhancing creative thinking. The results were analyzed by content analysis that the researchers obtained feedback and concluded as follows.

\section{Content}

Overall, the focus group discussion concluded and determined the content of the training package based on creative thinking should not be overwhelmed. The researchers selected only the content that was necessary to create training packages for the community. The trainees could learn these by themselves and have a simple task. Creating unit plans was in accordance with indicators in the eight learning areas. The development of activities to give the trainees the sample practice for learning activities would make them more understanding.

\section{Design of the training package}

The design of the training package of a paradigm development of community learning management for enhancing creative thinking for teachers in the smallsized school in Buri Ram Province should be as follows; 1) It should have explained in order that the trainees can be able to perform with the material step by step effectively (Corcoran \& Goertz, 1995), 2) It should consist of two or more types of media and design to encourage participants to understand the content of the training and more clearly in the activities, 3) It was a training package that can be used for self-study, 4) It was selfcontained media in the training package which allowed the trainer to choose from the training packages. This required the trainees to study a particular subject from the training package so that they will be able to select a particular subject, 5) There were activities in the nature of the exercises in the core curriculum of basic education in BE 2551. These activities were a part of the training activities in individual practice to provide the trainees with the opportunity to practice activities in accordance with the learning activities for the learners, and 6) The media took a short session to complete the training. If there were much content, it would be made up in separate units. The content is divided by the area of the content so that the trainees were not bored in the study.

\section{Learning Process}

There were four main components to the learning process namely Community, Learning, Technology, and Evaluation (CLTE). Learning process consists of four steps called PSRA; 1) 
Preparing, 2) Strategies, 3) Reflection, and 4) Assessing, described in Table 2.

Table 2. Stage of Learning Process

\begin{tabular}{|c|c|}
\hline Stage & Learning Process \\
\hline Preparing $(\mathrm{P})$ & 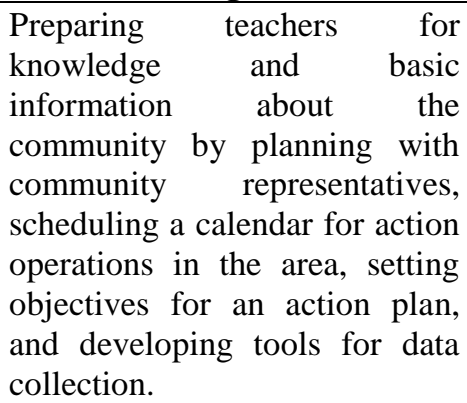 \\
\hline Strategi & $\begin{array}{l}\text { Choosing a variety of technics } \\
\text { to be suitable for learning } \\
\text { activities, there was an } \\
\text { integration of learning content } \\
\text { and used a variety of } \\
\text { technologies, appropriate } \\
\text { learning activities and different } \\
\text { learning technics. }\end{array}$ \\
\hline Reflecti & $\begin{array}{l}\text { The process that enabled } \\
\text { learning through thinking } \\
\text { processes and experiences } \\
\text { affected emotions and feelings. } \\
\text { The empirical information that } \\
\text { led to critical thinking helped } \\
\text { learners to learn and be self- } \\
\text { discovery (Edwards, 1950). It } \\
\text { could be done by writing a note, } \\
\text { reflection, question, interview, } \\
\text { and evaluation of learning } \\
\text { management. }\end{array}$ \\
\hline Assessing (A) & $\begin{array}{l}\text { Evaluated the activities of the } \\
\text { community-based learning } \\
\text { paradigm by assessing pre-test, } \\
\text { during the class assessment, } \\
\text { post-test, critical thinking } \\
\text { ability, and creative problem } \\
\text { solving (Halpern, 1998). }\end{array}$ \\
\hline
\end{tabular}

\section{Discussion}

The results of the development and the effectiveness of community learning management paradigm for enhancing creative thinking found that the community-based learning paradigm was high quality, structural integrity, and content. It was effective enough to use to learn. Covered by essential needs to enhance creative thinking for teachers in the small-sized school in Buri Ram Province, this may be due to a community-based learning paradigm developed systematically by using the result of basic information analysis related to the policy of educational management on standard of core curriculum in basic education BE 2551. It analyzed concept, theories and related researches to a paradigm development of community learning management for enhancing creative thinking and guidelines for organizing community learning activities (Davis, 1991). The statement is in line with Piaget's theory.

Piaget's theory of intellectual development and Vygotsky's social culture theory revealed that the context and community data which was the concept of a community-based learning paradigm was the basic learning management. This was consistent with the concept of developing learning management. It could be concluded that learning was a systematic approach to teach. It was correspondence with theories. Besides, there was a study on the state of teachers' learning management and learners' basic ability to learn. They could share their opinions about the problem and the way to organize the learning activities to promote creative thinking. This was the study of learning management. It aimed to implement to design the learning management.

From the constructivism theory, the researchers gave a guideline to organize learning activities for the learners to learn with the creative thinking process. It focused on learner-centered interaction and the real problem in the community. It was a subject that students were interested in solving the problems. They wanted to improve things to be better. It focused on cooperative learning by exploring community problems.

Then, students analyzed problems, planned solutions, practiced, and solved the problems with the solution planed, evaluated, checked, and finally presented by themselves. It also interacted with both people in the community and in the 
classroom. They could apply knowledge to daily life and expand to the community. Moreover, they could solve the problems in other situations. The researchers synthesized the guideline of learning management to enhance intelligent ability for creative thinking for seven sorts as follows (Guilford, 1956); 1) problems and issues, 2) preparation and data collection, 3) analysis, 4) data selection, 5) thinking and clarification, 6) synthesis and data collection, and 7) evaluation.

Then, the researchers put into process of learning management on community-based learning paradigm (Community-based learning: CBL) to be a guide to learning activities. It enhanced learners to have creative thinking by four learning processes of PSRA. After that, it was synthesized and set the guideline of learning management of a paradigm of community learning management for enhancing creative thinking. Finally, it was set the packages for three unit plans; 1) principle and theories of creative thinking, 2) community based learning for creative thinking, and 3) how to write the lesson plan to develop creative thinking process.

The researchers designed learning activities based on creative thinking for the trainees by considering alternative ways to solve the problems in new ways. There were Guilford s' creative thinking skills for seven sorts. So, the researchers used them to set the main components of learning management to enhance creative thinking for teachers in the small-sized school in Buri Ram Province. The results of effectiveness of a community based learning management paradigm on $\mathrm{E}_{1} / \mathrm{E}_{2}$ were based on the samples in this research. As a result, the effectiveness of a community based learning management paradigm was $81.20 / 82.50$.

This may involve participation in planning, co-thinking, co-operating, evaluating, transferring knowledge, informing, being proud, and taking responsibility for community-based learning management paradigms (CLTE). There were four components for community-based learning management paradigms. First, principles were community-based learning that took into account the four components of the CLTE such as community, learning management, technology, and evaluation by setting various learning management on the PSRA process. This encouraged students to learn by doing and solve the problems in the community with a variety of learning and creative tasks. Second, The objectives were to promote creative thinking for teachers in small-sized school. Third, the learning process consisted of four stages of PSRA, in which the learning activities must take into account four main components of the CLTE; 1) preparing to conference plan for jointed action between schools and the community provides basic education to students, 2) strategies to apply various learning techniques, 3) reflection to reflect the results of the community and student feedback to the paradigm of learning management, and 4) Assessing to be authentic assessment from all parties involved in the assessment. Fourth, the key to a successful learning paradigm consisted of 1) community supports and involving in every step, 2) teachers doing self-study in the community for practicing thinking and problem solving skill in real situations, and 3) plenty of time to organize appropriate learning activities outside the classroom.

The efficiency of the communitybased learning paradigm (CLTE), based on $E_{1} / E_{2}$ criteria, was used for this research. Moreover, the result showed that efficiency of community-based learning was 81.20/82.50. 
Table 3. Result of Efficiency of the Training Packages in the Experiment

\begin{tabular}{ccccccc}
\hline Effectiveness & Total Score & G.1 & G.2 & G.3 & $\overline{\boldsymbol{X}}$ & Percentage \\
& & 219 & 207 & 225 & 217 & 81.20 \\
\hline Process (E1) & 250 & \multicolumn{2}{c}{198.10} & & 82.50 \\
Product (E2) & 210 & \multicolumn{6}{c}{} \\
\hline
\end{tabular}

The effectiveness of a community based learning management paradigm to promote creative thinking for elementary students, the results were summarized as follows; 1) After a community based learning management paradigm (CLTE) session, teachers had the ability to think creatively after training session better than pre-training session statistically significant at .05 level. The teachers accepted the ability of creative thinking after training. The community based learning management paradigm was at a high level, with the average score being the ability of fluency thinking. The least average component was the ability of elaboration thinking. 2) After a community based learning management paradigm (CLTE) session, the teachers had higher level of creative thinking than the pre-training session at the .05 level. This indicated that teachers' level of creative thinking has developed. Test scores for creativity tests were higher than the scores higher. Considering the individual assessment, it found that overall teachers had a better ability of creative thinking after learning the paradigm of learning management using the community at a high level (Baxter \& Lederman, 1999). The lowest score was the knowledge building skills. One of the skills developed in this research is creative-thinking. The following is the result of students' creative-thinking in this research.

Table 4. Comparison of Results of Creative Thinking Test on Trainees Before and After Training

\begin{tabular}{ccccccc}
\hline Test & $\mathbf{n}$ & Total Score & $\overline{\boldsymbol{X}}$ & S.D. & t & Sig. \\
\hline Before training & 30 & 20 & 11.50 & 0.36 & & \\
After training & 30 & 20 & 14.25 & 0.18 & & 0.05 \\
\hline
\end{tabular}

In Table 4, the average score obtained before and after the training was improving. This happens because the learning management was able to improve the students' creative thinking. Through grouping, the students were able to combine their ideas and to construct creative ideas.

\section{CONCLUSION}

The findings of this research, are 1) the efficiency of a community-based learning paradigm to promote creative thinking for teachers in the small-sized school in Buri Ram Province was $81.20 / 82.50,2$ ) the effectiveness of a community-based learning paradigm to promote creative thinking for teachers in the small-sized school in Buri Ram
Province was that post-training session based on the paradigm of communitybased learning management was higher than pre-training session significantly at .05 , and 3) satisfaction in developing a community-based learning paradigm to promote creative thinking for teachers in the small-sized school in Buri Ram Province was very high.

\section{REFERENCES}

Baxter, J. A., \& Lederman, N. G. (1999). Assessment and Measurement of Pedagogical Content Knowledge. Examining Pedagogical Content Knowledge: The Construct and Its Implications for Science Education. Dordrecht, the Netherlands: Kluwer Academic Publishers, 147-161. 
Biggs, J. B. (1999). Teaching for Quality Learning at University. Philadelphia: Society for research into higher education and open university press.

Borg, W. R., \& Gall, M. D. (2003). Educational Research: An Introduction. London: Longman Inc.

Borg, W. R., Kallenbach, W., Morris, M., \& Friebel, A. (1969). Videotape Feedback and Microteaching: a Teacher Training Model. Micro teaching, Component Skills and the Training of Teachers: an Evaluation of a Research and Development Project.

Burke, B. ., Sears, S. ., Kraus, S., \& Cady, S. . (2014). Critical Analysis: A Comparison of Critical Thinking Changes in Psychology and Philosophy Classes. Teaching of Psychology, 41(1), 28-36. https://doi.org/10.1177/00986283135 14175

Chang, C. Y., Chang, Y. H., \& Yang, F. Y. (2009). Exploring Secondary Science Teachers' Perceptions on the Goals of Earth Science Education in Taiwan. International Journal of Science Education, 31(17), 2316.

Chantarasomabat, C., Udombunyanuparb, N., \& Kenchaiwong, N. (2017). Development of Innovation enhances Learning Achievement of Educational Schools in Northeastern Thailand under the Office of the Basic Education Commission. Journal of Education, Mahasarakham University, 11(2), 171-183.

Corcoran, T., \& Goertz, M. (1995). Instructional Capacity and High Performance Schools. Educational Research, 24(9), 27-31.

Davis, G. . (1991). Teaching Creative Thinking (Handbook of gifted education). Boston: Allyn and Bacon.

Divan, A., \& Mason, S. (2015). A programme-wide training framework to facilitate scientific communication skills development amongst biological sciences Masters students. Journal of Further and Higher, 125.

https://doi.org/10.1080/0309877X.20 14.1000276

E, J. (2000). Brain-based Learning. San Diego, CA: The Brain Store. Journal of Educational Research, Taylor \& Francis, Ltd, 131-141.

Edwards, T. (1950). Measurement of Some Aspects of Critical Thinking. Journal of Experimental Education, 18, 263-278.

Fernández, M. B. (2018). Framing Teacher Education: Conceptions of Teaching, Teacher Education, and Justice in Chilean National Policies. Education Policy Analysis Archives, 26(34), 1-37. Retrieved from http://epaa.asu.edu/ojs/

Francis, M, D., L, S., \& Colbry. (2016). Campus Community Integration on a Mission: Transformative Learning for Social Change, in Laura A. Wankel , Charles Wankel (ed.) Integrating Curricular and CoCurricular Endeavors to Enhance Student Outcomes, 289-319.

Gardner, H. (2010). Five Minds for the Future" 21st Century Skills: Rethinking How Students Learn. (J. Brandt \& R. Bellanca, Eds.). Bloomington: Solution tree press.

Good, C. V. (1973). Dictionary of Education (3rd ed.). New York: McGraw-Hill.

Guilford, J. . (1956). Structure of Intellect Psychological. New York: McGrawHill Book Co.

Halpern, D. (1998). Teaching critical thinking for transfer across domains: Disposition, skills, structure training, and metacognitive monitoring. American Psychologist, 53, 449-455.

Haruthaithanasan, T. (2018). Effects of educational reforms in the 2nd decade ( 2009-2018) on teacher motivation and student achievement among schools in Southern Thailand. 
Kasetsart Journal of Social Sciences, (2017), 4-11. https://doi.org/10.1016/j.kjss.2017.0 6.008

Marzano, R. . (2003). What works in schools: Translating research into action. Alexandria. VA: Association for Supervision and Curriculum Development.

Murphy, F., \& Timmins, F. (2009). Experience based learning (EBL): Exploring Professional teaching through critical reflection and reflexivity. Nurse Education in Practice, 9(1), 72-80.

Mutakinati, L., Anwari, I., \& Yoshisuke, K. (2018). Analysis Of Students' Critical Thinking Skill of Middle School Through Stem Education Project-Based Learning. Jurnal Pendidikan IPA Indonesia, 7(1), 5465. https://doi.org/10.15294/jpii.v7i1.10 495

Nesterova, M. (2017). Educational Cognitive Technologies as Human Adaptation Strategies. Future Human Image, 7, 102-112.

Selvi, K. (2006). Learning and Creativity. Analecta Husserlisna: The Yearbook of Phenomenological Research, 63, 351-369.

Shernoff, D. J., Sinha, S., Bressler, D. M., \& Ginsburg, L. (2017). Assessing Teacher Education and Professional Development Needs for the Implementation of Integrated Approaches to STEM Education. International Journal of STEM Education, 4(13), 1-16. https://doi.org/10.1186/s40594-0170068-1

Sheydaei, M., Adibsereshki, N., \& Movallali, G. (2015). The Effectiveness of Emotional Intelligence Training on Communication Skills in Students with Intellectual Disabilities. Iranian Rehabilitation Journal, 13(3), 7-12.

Siri, R., \& Chantraprayoon, O. S. (2017). Local community participatory learning with a nature interpretation system: A case study in Ban Pong, Sansai disctric, Chiang Mai, Thailand. Kasetsart Journal of Social Sciences, 38(2), 181-185. https://doi.org/10.1016/j.kjss.2016.0 4.003

Torrance, E. ., \& Myers, R. E. (1962). Creative Learning and Teaching. New York: Good, Mead and Company.

Wallach, M. A., \& Nathan, K. (1965). Model of Thinking in Young Children. New York: Holt, Rinehartandwinston.

Yin, R. K. (2003). Case study research: Design and methods (3rd ed.). Thousand Oaks, CA: Sage.

Y1ldırım, G., \& Akamca, G. Ö. (2017). The effect of outdoor learning activities on the development of preschool children. South African Journal of Education, 37(2), 1-10. https://doi.org/10.15700/saje.v37n2a 1378

Yoon, H., Woo, A. J., Treagust, D., \& Chandrasegaran, A. L. (2014). The Efficacy of Problem-based Learning in an Analytical Laboratory Course for Pre-service Chemistry Teachers. International Journal of Science Education, 36(1), 79-102. https://doi.org/10.1080/09500693.20 12.727041 